\title{
Configurational crop heterogeneity increases within-field plant diversity
}

\author{
Audrey Alignier ${ }^{1,2}$ (i) | Xavier O. Solé-Senan3 (i) | Irene Robleño3 | Bàrbara Baraibar ${ }^{3,4}$ \\ Lenore Fahrig $^{5}$ (D) | David Giralt ${ }^{6}$ (D) | Nicolas Gross ${ }^{7,8,9}$ (D) | Jean-Louis Martin ${ }^{10}$ \\ Jordi Recasens $^{3}$ (D) | Clélia Sirami ${ }^{10,11}$ (D) | Gavin Siriwardena ${ }^{12}$ | Aliette Bosem Baillod ${ }^{13,14}$ \\ Colette Bertrand $d^{1,15}$ (D) | Romain Carrié ${ }^{11,16}$ | Annika Hass ${ }^{13,17}$ (D) | Laura Henckel ${ }^{7,8,18}$ | \\ Paul Miguet ${ }^{7,8,18}$ (D) | Isabelle Badenhausser ${ }^{7,8,19}$ (D) | Jacques Baudry ${ }^{1}$ (D) | \\ Gerard Bota $^{6}$ | Vincent Bretagnolle,18 (i) | Lluis Brotons ${ }^{20,21,22}$ | Françoise Burel ${ }^{15}$ | \\ François Calatayud $^{11}$ | Yann Clough ${ }^{13,16}$ | Romain Georges ${ }^{2,15}$ | Annick Gibon ${ }^{11}$ | \\ Jude Girard $^{5}$ | Kathryn Lindsay ${ }^{5}$ (D) | Jesus Minano ${ }^{20}$ | Scott Mitchell ${ }^{5}$ (D) | \\ Nathalie Patry $^{23}$ | Brigitte Poulin ${ }^{23}$ | Teja Tscharntke ${ }^{13}$ | Aude Vialatte ${ }^{11}$ | \\ Cyrille Violle $^{10}$ | Nicole Yaverscovski ${ }^{23}$ | Péter Batáry ${ }^{24}$
}

\begin{abstract}
${ }^{1}$ UMR 0980 BAGAP, INRAE - Institut Agro - ESA, Rennes Cedex, France; ${ }^{2}$ LTSER "Zone Atelier Armorique", Rennes Cedex, France; ${ }^{3}$ ETSEA, Agrotecnio, Department HBJ, Universitat de Lleida, Lleida, Spain; ${ }^{4}$ The Pennsylvania State University, University Park, State College, PA, USA; ${ }^{5}$ Geomatics and Landscape Ecology Laboratory, Department of Biology, Carleton University, Ottawa, ON, Canada; ${ }^{6}$ CTFC Forest Science and Technology Centre of Catalonia, Solsona, Catalonia, Spain; ${ }^{7}$ Centre d'Etudes Biologiques de Chizé, UMR 7372, CNRS - Université de La Rochelle, Villiers en Bois, France; ${ }^{8}$ USC 1339 Station d'Ecologie de Chizé - La Rochelle, INRAE, Niort, France; ${ }^{9}$ UCA, INRAE, VetAgro Sup, UMR Ecosystème Prairial, Clermont-Ferrand, France; ${ }^{10}$ UMR 5175 CEFE, CNRS Université de Montpellier - EPHE - IRD, Montpellier Cedex 5, France; ${ }^{11}$ UMR 1201 Dynafor, Université de Toulouse - INRAE - INPT - EI PURPAN, CastanetTolosan, France; ${ }^{12}$ British Trust for Ornithology, Norfolk, UK; ${ }^{13}$ Agroecology, Department for Crop Sciences, University of Goettingen, Göttingen, Germany; ${ }^{14}$ Agroscope, Zurich, Switzerland; ${ }^{15}$ UMR 6553 ECOBIO, CNRS, Rennes, France; ${ }^{16}$ Centre for Environmental and Climate Research, Lund University, Lund, Sweden; ${ }^{17}$ Functional Agrobiodiversity, Department for Crop Sciences, University of Goettingen, Göttingen, Germany; ${ }^{18}$ LTSER "Zone Atelier Plaine \& Val de Sèvre", Villiers en Bois, France; ${ }^{19}$ URP3F, INRAE, Lusignan, France; ${ }^{20}$ InForest Joint Research Unit (CTFC-CREAF), Solsona, Spain; ${ }^{21}$ CREAF, Bellaterra, Spain; ${ }^{22}$ CSIC, Cerdanyola del Vallès, Spain; ${ }^{23}$ Tour du Valat Research Institute for the Conservation of Mediterranean Wetlands, Le Sambuc, Arles, France and

${ }^{24}$ MTA Centre for Ecological Research, Institute of Ecology and Botany, "Lendület" Landscape and Conservation Ecology, Vácrátót, Hungary
\end{abstract}

Correspondence

Audrey Alignier

Email: audrey.alignier@inrae.fr

Funding information

Natural Sciences and Engineering Research Council of Canada; German Ministry of Research and Education; Agence Nationale de la Recherche, Grant/Award Number: ANR-11-EBID-0004; Canada Foundation for Innovation; German Research Foundation; Spanish Ministry of Economy and Competitiveness; Agriculture and AgriFood Canada; French National Research Agency, Grant/Award Number: ANR-11EBID-0004; UK Government Department of the Environment, Food and Rural Affairs; Environment Canada (EC)

Handling Editor: Pieter De Frenne

\section{Abstract}

1. Increasing landscape heterogeneity by restoring semi-natural elements to reverse farmland biodiversity declines is not always economically feasible or acceptable to farmers due to competition for land. We hypothesized that increasing the heterogeneity of the crop mosaic itself, hereafter referred to as crop heterogeneity, can have beneficial effects on within-field plant diversity.

2. Using a unique multi-country dataset from a cross-continent collaborative project covering 1,451 agricultural fields within 432 landscapes in Europe and Canada, we assessed the relative effects of compositional and configurational crop heterogeneity on within-field plant diversity components. We also examined how these relationships were modulated by the position within the field.

3. We found strong positive effects of configurational crop heterogeneity on withinfield plant alpha and gamma diversity in field interiors. These effects were as high as the effect of semi-natural cover. In field borders, effects of crop heterogeneity 
were limited to alpha diversity. We suggest that a heterogeneous crop mosaic may overcome the high negative impact of management practices on plant diversity in field interiors, whereas in field borders, where plant diversity is already high, landscape effects are more limited.

4. Synthesis and applications. Our study shows that increasing configurational crop heterogeneity is beneficial to within-field plant diversity. It opens up a new effective and complementary way to promote farmland biodiversity without taking land out of agricultural production. We therefore recommend adopting manipulation of crop heterogeneity as a specific, effective management option in future policy measures, perhaps adding to agri-environment schemes, to contribute to the conservation of farmland plant diversity.

\section{KEYWORDS}

biodiversity conservation, crop mosaic, diversity partitioning, farmland, field border, landscape composition, landscape configuration, weed

\section{INTRODUCTION}

Since the mid-20th century, agricultural intensification has led to the conversion of complex mosaic agricultural landscapes into highly productive arable land, through field enlargement, expansion of crop areas and simplified crop rotations (Foley et al., 2011). The resulting landscape homogenization and increasing use of chemical inputs are recognized as major drivers of dramatic losses of farmland biodiversity and associated ecosystem services (Newbold et al., 2015; Norris, 2008). To stop or to reverse farmland biodiversity declines, several studies have recommended the restoration of landscape heterogeneity (Benton, Vickery, \& Wilson, 2003; Roschewitz, Gabriel, Tscharntke, \& Thies, 2005). Increasing landscape heterogeneity by increasing the amount of semi-natural elements may, however, not be economically feasible or acceptable to farmers (Burton, Kuczera, \& Schwarz, 2008). Therefore, an alternative management strategy would be to consider whether increasing the heterogeneity of the crop mosaic itself in the landscape can provide equivalent benefits (Fahrig et al., 2011).

Within-field plants, here defined as wild, unsown plants in agricultural fields, are an important component of farmland biodiversity. They play a crucial role in supporting biological diversity by providing food and shelter for a wide variety of animals such as auxiliary insects for example, carabids, pollinators and birds (Bretagnolle \& Gaba, 2015; Marshall et al., 2003; Storkey, 2006). While a large body of literature has focused on the effects of farming practices on within-field plant diversity, an increasing number of empirical studies suggest that landscape-scale factors should also be considered (Alignier, Petit, \& Bohan, 2017; Roschewitz et al., 2005; Solé-Senan et al., 2014).

The heterogeneity of the crop mosaic, hereafter referred to as crop heterogeneity, can be decomposed into two distinct components: compositional and configurational crop heterogeneity. Compositional crop heterogeneity refers to the composition of the crop mosaic, that is, the diversity of crop cover types. Configurational crop heterogeneity refers to the shape and spatial arrangement of crop fields which can be measured as the mean size of fields or edge density (Fahrig et al., 2011). The effects of compositional and configurational crop heterogeneity on species diversity are rarely disentangled because they are typically highly correlated (Kareiva, Watts, McDonald, \& Boucher, 2007).

The few attempts to tease apart the effects of crop heterogeneity components on species diversity have found positive effects of compositional crop heterogeneity, that is, Shannon crop diversity and/or configurational crop heterogeneity, that is, edge density or mean field size, on predatory arthropods (Bertrand, Burel, \& Baudry, 2016; Bosem Baillod, Tscharntke, Clough, \& Batáry, 2017; Fahrig et al., 2015; Martin et al., 2019; Palmu, Ekroos, Hanson, Smith, \& Hedlund, 2014), butterflies (Perović et al., 2015) and wild bees (Hass et al., 2018). Studies addressing this issue for the diversity of plants within agricultural fields are rarer (but see Fahrig et al., 2015).

Both components of crop heterogeneity may theoretically benefit within-field plant diversity. Studies at the national scale in Europe have identified crop type as the most determinant factor of plant species composition within fields (Fried, Petit, Dessaint, \& Reboud, 2009; Lososová et al., 2004). Therefore, diversifying crop types at the landscape scale, that is, increasing compositional crop heterogeneity, should increase the plant species pool in the landscape by creating more niche opportunities (Benton et al., 2003; Marshall, 2009). By extension, the probability that new plant species (i.e. plant species that were not present already) immigrate into a field would be greater when the proportion and the diversity of alternative crop habitats in the landscape are increased, leading to higher local species richness (Auerbach \& Shmida, 1987). Decreasing mean field size, that is, increasing configurational crop heterogeneity, should promote the migration of short-distance dispersal plant species, facilitate their access to field interiors from neighbouring non-crop 
features or adjacent crop fields (i.e. cross-habitat spillover; Henckel, Börger, Meiss, Gaba, \& Bretagnolle, 2015; Tscharntke et al., 2012) and increase local species richness in agricultural fields.

In this paper, we assess the relative effects of compositional and configurational crop heterogeneity on within-field diversity of plants. We use a unique dataset from a cross-continent collaborative project (http://www.farmland-biodiversity.org/) covering 1,451 agricultural fields, located in Europe and Canada, along uncorrelated gradients of compositional and configurational crop heterogeneity. To our knowledge, this is the first multi-country study investigating how landscape heterogeneity of the crop mosaic is modulating alpha, beta and gamma diversity of plants in agricultural fields. We predicted that increasing compositional and configurational crop heterogeneity would increase within-field plant diversity. Field borders and field interiors may differ in non-crop plant diversity due to spatial differences in the impact of farming practices which is higher towards field interiors, and the limited plant seed dispersal from adjacent crop and non-crop features (José-María, Armengot, Blanco-Moreno, Bassa, \& Sans, 2010; Poggio, Chaneton, \& Ghersa, 2013). The spatial differences in plant diversity within fields can indeed be attributed to the higher efficacy of farming practices (crop sowing, fertilization and weed control) that may limit noncrop species occurrence in field interiors compared to field borders. Moreover, the importance of the surrounding landscape which is a source of species seed pool, is expected to decrease with increasing distance to field borders (José-María et al., 2010; Petit et al., 2013). We thus examined how relationships between crop heterogeneity and plant diversity were modulated by the position within the field. We predicted that the effect of compositional crop heterogeneity on alpha, beta and gamma plant diversity would be identical in field borders and interiors. Conversely, we predicted that the effect of configurational crop heterogeneity would be stronger on alpha, beta and gamma plant diversity in field borders than in field interiors due to higher probability of seed dispersal events from adjacent crop and non-crop features.

\section{2 | MATERIALS AND METHODS}

\subsection{Region and landscape selection}

The study was conducted in eight agricultural regions comprising seven regions in Europe and one region in eastern Canada (near Ottawa; Figure 1). The European regions followed a south-to-north gradient, with four regions in France (near Arles, Niort, Rennes, Toulouse), one in England (centred on Ely, Cambridgeshire), one in Germany (near Goettingen) and one in Spain (near Lleida; Figure 1). Within these agricultural regions, we selected a total of $4321 \times 1 \mathrm{~km}$ landscapes, with $60 \%-90 \%$ of crop cover in each. These landscapes represented, by design, uncorrelated gradients of compositional crop heterogeneity, assessed by the Shannon diversity index of the crop cover types, and of configurational crop heterogeneity, assessed by the total length of crop field borders (see Pasher et al., 2013;
Sirami et al., 2019 for details). The landscape selection process used the most recent remotely sensed data or land cover map available for each agricultural region (see Table S1).

While land cover maps were adequate for landscape selection, their coarse spatial resolution did not allow for the accurate delineation of narrow strips of non-crop covers between fields. By consequence, all landscapes were digitized from aerial photos to create detailed maps delineating all fields managed for agricultural production (including crops, and temporary and permanent grasslands), linear semi-natural boundaries between crop fields and non-crop patches. Non-crop cover types included woodland, open land, wetland and built-up areas. Linear semi-natural boundaries included hedgerows, grassy strips and watery boundaries such as ditches. These maps were visually validated by field crews within each agricultural region before the sampling of the vegetation in a given landscape.

Based on these more accurate and recent maps, several landscape variables were calculated. Compositional crop heterogeneity was assessed using the Shannon diversity index of agricultural cover types as $S H D I=-\sum_{i=1}^{n} p_{i} \ln p_{i}$, where $p_{i}$ is the proportion of crop cover type $i$ (including grasslands) in the agricultural mosaic. Configurational crop heterogeneity was measured as the total field border length (TBL). TBL was the sum of perimeters of all fields within the $1 \times 1 \mathrm{~km}$ landscape minus the length of perimeters artificially created by intersection with the limits of the $1 \times 1 \mathrm{~km}$ landscape. The percentage of semi-natural cover types (SemiNatCover) was calculated as the sum of the proportions of woodland, open land and wetland in the landscape. The length of semi-natural boundaries (SemiNatBound) was calculated as half of the sum of the perimeter of woody, grassy and watery boundaries in the landscape. We checked for correlations among landscape variables to avoid distortion in models caused by multi-collinearity. There was no collinearity between SHDI and TBL (Pearson correlation test, $r=.01, p=.62$; Figure S1). Due to strong correlation between SemiNatBound and TBL $(r=.70, p<.01$; Table S2), only TBL was kept in further analyses. We used a subset of our dataset for which SemiNatBound and TBL were not strongly correlated, to verify that this correlation did not affect our conclusions (see Appendix S1 in Supporting Information). The average value and range of the four landscape variables are presented in Table 1.

\subsection{Sampling site selection}

Within each landscape, we selected three to four sampling sites. Sampling sites were fields managed for agricultural production including crops, temporary and permanent grasslands. Fields were selected such that at least one contained the dominant crop type in the region, the other fields being representative of crops present within the focal landscape (Table S3). Fields were at least $200 \mathrm{~m}$ apart, at least $50 \mathrm{~m}$ away from the border of the $1 \times 1 \mathrm{~km}$ landscape and at least $50 \mathrm{~m}$ away from large non-crop cover type patches such as woodland. We selected fields bordered by a similar boundary type 


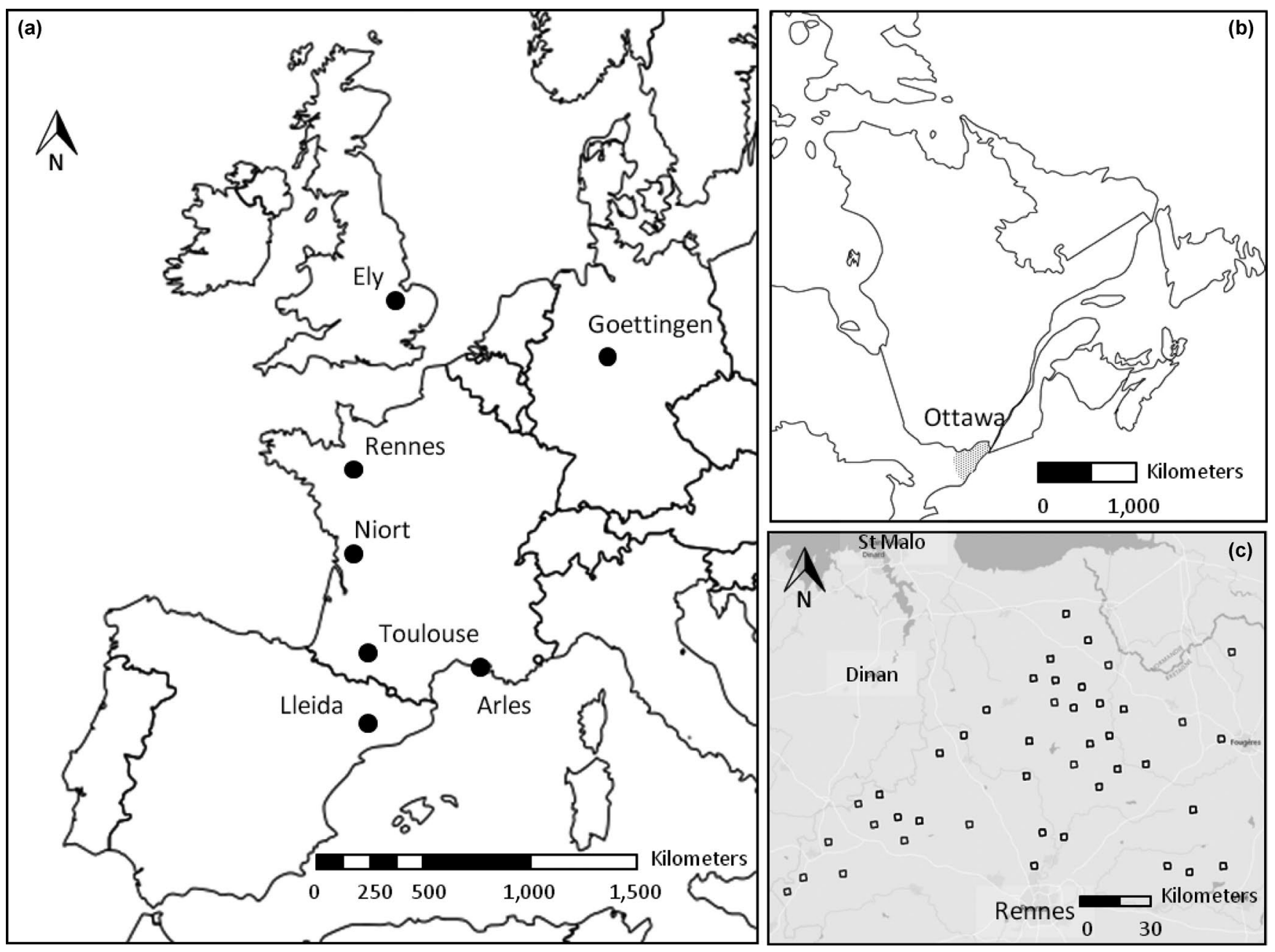

FIGURE 1 Location (nearest big city) of the eight study sites in (a) Europe and (b) eastern Ontario, Canada (sample landscapes spread through the shaded region of Ontario, with arrow pointing at the largest city, Ottawa, at the north edge of the region for context). (c) Illustration of the location of $1 \times 1 \mathrm{~km}$ sample landscapes in one of the eight regions (near Rennes in Brittany, France)

\begin{tabular}{|llrlr|}
\hline Code & Variable & M \pm SE & Min & Max \\
\hline SHDI & Shannon crop diversity index & $1.02 \pm 0.39$ & 0 & 2.03 \\
\hline TBL & $\begin{array}{l}\text { Total length of crop borders } \\
\text { (in kilometres) }\end{array}$ & $19.25 \pm 7.71$ & 5.76 & 60.13 \\
\hline SemiNatCover & $\begin{array}{c}\text { Proportion of semi-natural } \\
\text { cover types (in \%) }\end{array}$ & $12.72 \pm 9.03$ & 0 & 49.52 \\
\hline SemiNatBound & $\begin{array}{l}\text { Length of semi-natural } \\
\text { boundaries (in kilometres) }\end{array}$ & $5.63 \pm 3.82$ & 0 & 29.79 \\
\hline
\end{tabular}

TABLE 1 Average, standard error and range of landscape explanatory variables across all regions within each region, that is, only grassy strips or hedgerows, wherever possible. In total, 1,451 agricultural fields were sampled.

\section{3 | Vegetation sampling}

Within each sampling site, we surveyed within-field plant species along two parallel, $1 \mathrm{~m}$ wide and $50 \mathrm{~m}$ long transects, one located on the field border, the other within the field interior resulting in
2,788 transects surveyed. Transects were about $25 \mathrm{~m}$ distant from each other. We sampled five plots $(4 \times 1 \mathrm{~m})$ along each transect, that is, $20 \mathrm{~m}^{2}$ per transect (Figure 2). Note that in Ottawa, transects were $2 \mathrm{~m}$ wide and the field border transect encompassed part of the boundary vegetation. We verified that this slight difference in sampling protocol did not affect our conclusions (Appendix S2). Percentage cover of all vascular plant species was recorded. We conducted these plant surveys over 2 years between 2011 and 2014, each sampling site being sampled only within a single year. 
FIGURE 2 Illustration of the sampling design and within-field plant diversity components. Within each sampling site, we surveyed within-field plant species along two transects, one located on the field border, the other within the field interior. Gamma diversity $(\gamma)$ was the total number of species across all plots sampled in a given transect and alpha $(\alpha)$ diversity was the number of within-field plant species present in each plot averaged across the five plots per transect. Beta diversity $(\beta)$ describes how many more species are present in the whole transect than at an average plot

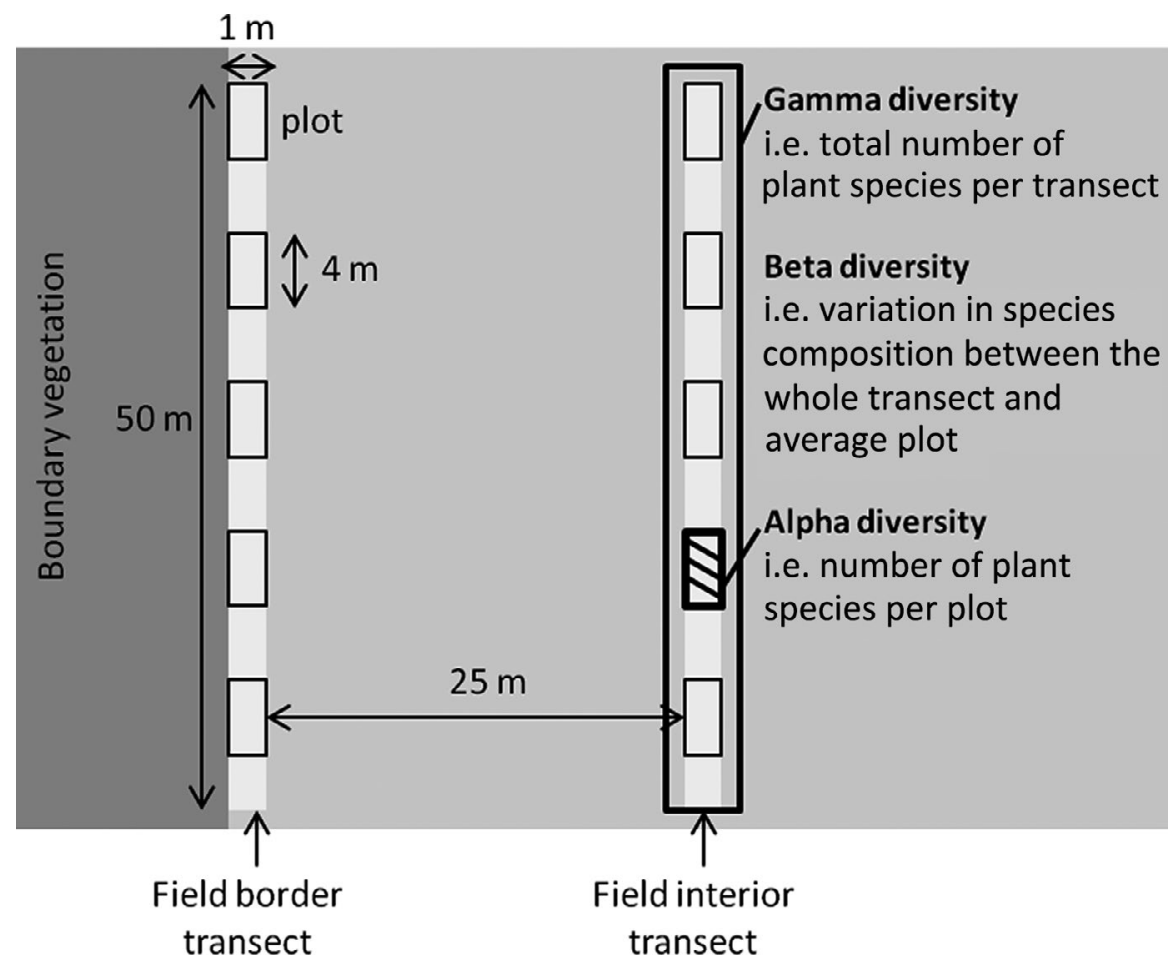

Surveys were conducted once before crop harvesting, except in Ely, Goettingen and Ottawa where surveys were conducted twice (Table S4). In those regions, we pooled within-field plant data from the two visits per year and retained the total number of plant species for each sampled plot. Plant nomenclature followed TaxRef (Gargominy et al., 2014).

\section{4 | Data analysis}

Following Whittaker (1972), we used the multiplicative diversity partitioning method to assess plant species diversity components where $\beta=\gamma / \alpha$. Gamma diversity $(\gamma)$ was the total number of species across all plots sampled in a given transect and alpha $(\alpha)$ diversity was the number of within-field plant species present in each plot averaged across the five plots per transect (Figure 2). This measure of beta diversity $(\beta)$ describes variation in plant species composition in the whole transect by comparison with an average plot.

We analysed variations in alpha, beta and gamma plant diversity using linear mixed-effects models (LMMs). Compositional and configurational crop heterogeneity (SHDI and TBL), and their interaction with within-field position (field border vs. field interior, $P O S$ ) and the proportion of semi-natural cover types (SemiNatCover) were included as fixed effects. To allow for direct comparison of the estimated coefficients and for rigorous treatment of interactions (Grueber, Nakagawa, Laws, \& Jamieson, 2011), all response variables (alpha, beta and gamma diversity) and explanatory variables were centred and scaled across all regions. The partially cross-nested random structure (due to transects being sampled in the same field and different crop types being sampled in different regions, as well as different crop types being sampled in landscapes of the same region) was taken into account in the random structure of the models. The model formula was:

Model 1:y SHDI + TBL + POS + SemiNatCover +SHDI:TBL +SHDI:POS

\section{+ TBL:POS + SemiNatCover:SHDI + SemiNatCover:TBL}

+SemiNatCover:POS+ (1|Region/Landscape)

$+(1 \mid$ Region/Langscape $)+(1 \mid$ Region/Croptree $))+(1 \mid 1$ Dfield $)$.

Visual inspection of residual plots reveal no large deviations from homoscedasticity or normality. We then performed a multi-model inference procedure based upon the bias-corrected Akaike information criterion $(\mathrm{AIC})$. We built all possible alternative candidate models based on the linear additive functions of explanatory variables. We averaged the parameters of all models for which the respective variables were present. We considered variables as significant when confidence intervals did not include zero (Burnham \& Anderson, 2002). Finally, we estimated variance explained by models using the marginal and conditional pseudo- $R^{2}$ statistic (Nakagawa \& Schielzeth, 2013). Statistical analyses were carried out using the LME4 package for mixed models (Bates, Maechler, Bolker, \& Walker, 2015) and MuMIN for multi-model inference (Barton, 2017) in R 3.2.3 (R Core Team, 2015).

\section{3 | RESULTS}

We recorded a total of 899 plant species across the eight agricultural regions. Each region contained $16 \%-33 \%$ of the total species richness.

Alpha diversity ranged from 0.4 to 42 and averaged 10.5 (SE = 6.5) in field border transects. Alpha diversity ranged from 0.2 to 30.6 and averaged $5.8(S E=5.2)$ in field interior transects. Within-field 
position (POS) had a strong independent effect on alpha diversity (Table 2). Alpha diversity was twice as high in field borders as in field interiors. Configurational crop heterogeneity (TBL) had a significant effect through an interaction with within-field position (POS). TBL had a strong positive effect on alpha diversity in field interiors but no effect on alpha diversity in field borders (Figure 3; Appendix S3).

TABLE 2 Model-averaged standardized estimates, standard errors and $p$ values from linear mixed-effects models of alpha, beta and gamma within-field plant diversity in relation to compositional and configurational crop heterogeneity, within-field position and the amount of semi-natural cover. Data are from 2,788 transects pertaining to $4321 \times 1 \mathrm{~km}$ landscapes in eight agricultural regions. Six transects were sampled in each landscape, one at the edge and one in the interior of each of three agricultural fields. Each transect contained five plots, over which the diversity measures were calculated (see Figure 1)

\begin{tabular}{|c|c|c|c|c|c|c|c|c|c|}
\hline & \multicolumn{3}{|c|}{ Alpha diversity } & \multicolumn{3}{|c|}{ Beta diversity } & \multicolumn{3}{|c|}{ Gamma diversity } \\
\hline Intercept & 0.358 & 0.142 & $*$ & -0.113 & 0.102 & ns & 0.401 & 0.143 & ** \\
\hline SHDI & 0.031 & 0.027 & ns & 0.017 & 0.027 & ns & 0.043 & 0.027 & ns \\
\hline TBL & -0.022 & 0.036 & ns & 0.045 & 0.040 & ns & 0.007 & 0.036 & ns \\
\hline$S H D I \times T B L$ & 0.001 & 0.022 & ns & 0.036 & 0.023 & ns & 0.010 & 0.021 & ns \\
\hline$S H D I \times P O S$ & 0.043 & 0.026 & ns & 0.012 & 0.035 & ns & 0.048 & 0.025 & ns \\
\hline$T B L \times P O S$ & 0.213 & 0.026 & $* * *$ & -0.125 & 0.034 & $* * *$ & 0.170 & 0.026 & $* * *$ \\
\hline SemiNatCover $\times$ SHDI & 0.017 & 0.022 & ns & -0.020 & 0.022 & ns & 0.016 & 0.021 & ns \\
\hline Marginal $R^{2}$ & \multicolumn{3}{|c|}{.22} & \multicolumn{3}{|c|}{.02} & \multicolumn{3}{|c|}{.24} \\
\hline
\end{tabular}

Abbreviations: ns, not significant; POS, within-field position; SemiNatCover, proportion of semi-natural cover types in the landscape; SHDI, Shannon crop diversity index; TBL, total length of crop borders.

${ }^{*} p<.05,{ }^{* *} p<.01,{ }^{* * *} p<.001$.

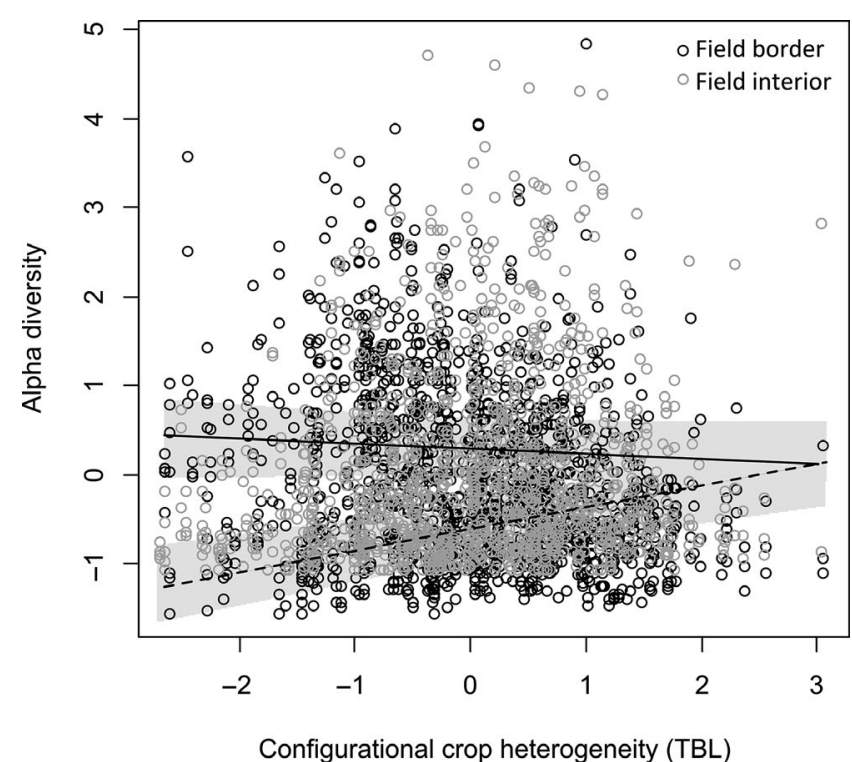

FIGURE 3 Interaction plot of the effect on alpha diversity (i.e. mean plot species diversity) of within-field plants with configurational crop heterogeneity measured as the total crop border length (TBL), according to within-field position. The dotted line fits field interior transects, whereas the solid line fits field border transects. Grey zones delimit the confidence intervals at $95 \%$. Note that variables are centred and scaled

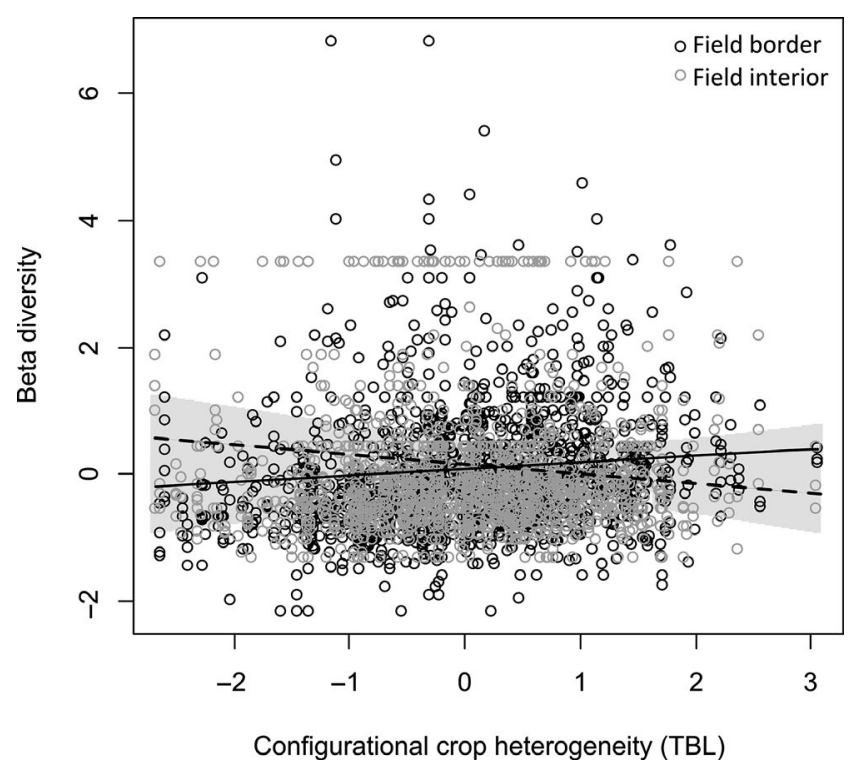

FIGURE 4 Interaction plot of the effect on beta diversity (i.e. ratio between gamma and alpha diversity) of within-field plants with configurational crop heterogeneity measured as the total crop border length (TBL), according to within-field position. The dotted line fits field interior transects, whereas the solid line fits field border transects. Grey zones delimit the confidence intervals at 95\%. Note that variables are centred and scaled 


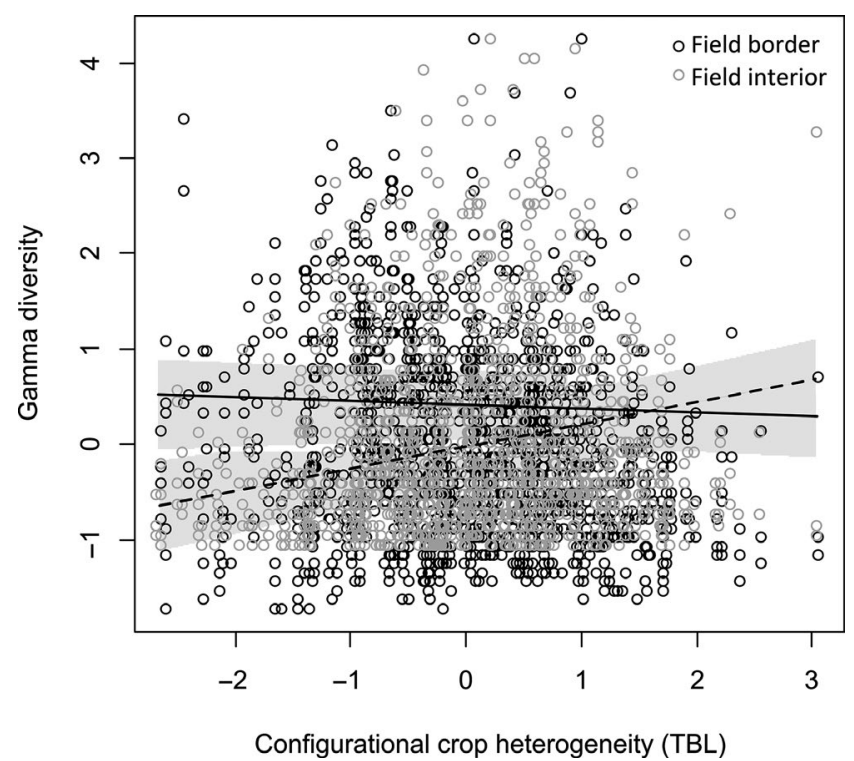

FIGURE 5 Interaction plot of the effect on gamma diversity (i.e. total number of species across all five plots sampled in a transect) of within-field plants with configurational crop heterogeneity measured as the total crop border length (TBL), according to within-field position. The dotted line fits field interior transects, whereas the solid line fits field border transects. Grey zones delimit the confidence intervals at $95 \%$. Note that variables are centred and scaled

SemiNatCover also had a positive effect on alpha diversity, alone or in interaction with POS (Table 2; Appendix S3).

Beta diversity ranged from 1 to 5 and averaged 1.95 (SE = 0.44) in field border transects and $2.13(S E=0.85)$ in field interior transects. Within-field position (POS) had a strong independent effect on beta diversity (Table 2). The only landscape variable to have a significant effect on beta diversity was configurational crop heterogeneity (TBL), through an interaction with within-field position (POS) (Figure 4). However, when separating field border transects and field interior transects, the effects of TBL were no longer significant (Appendix S3). SHDI and SemiNatCover, alone or in interaction, had no significant effect on beta diversity (Table 2 ).

Gamma diversity ranged from 1 to 65 in field border transects and from 1 to 50 in field interior transects. Gamma diversity was on average twice as high in field borders $(M=19.4, S E=10.7)$ as in field interiors ( $M=10.8, S E=9.2$ ). Configurational crop heterogeneity $(T B L)$ had significant interacting effects with POS on gamma diversity (Table 2). $T B L$ had strong positive effects on gamma diversity in field interior transects but no effect on gamma diversity in field border transects (Figure 5; Appendix S3). SemiNatCover, alone or in an interaction with $\mathrm{POS}$, had a significant and positive effect on gamma diversity (Table 2; Appendix S3).

\section{4 | DISCUSSION}

This study provides the first multi-country evidence that crop heterogeneity drives plant diversity within agricultural fields. As hypothesized, we showed that responses of within-field plant diversity to crop heterogeneity were modulated by the position within the field.

Alpha and gamma plant diversity increased with increasing configurational crop heterogeneity in field interior transects. Because of their high disturbance levels compared to natural ecosystems, agricultural fields are usually seen as depauperate features sheltering only a small proportion of the regional plant species pool (Landis \& Marino, 1999). Heterogeneous agricultural landscapes contain a diversity of crop types which can enlarge the landscape-level plant species pool from which local communities are drawn (Tscharntke, Klein, Kruess, Steffan-Dewenter, \& Thies, 2005), resulting in higher local species richness. The strong positive effect of increasing configurational crop heterogeneity on alpha and gamma plant diversity in field interior transects is consistent with the findings of Fahrig et al. (2015) and Sirami et al. (2019). In landscapes with higher field border length, the probability of short-distance dispersal events being successful is enhanced. Thus, immigration towards the inner field from the neighbourhood is facilitated through mass effect (Henckel et al., 2015; Shmida \& Wilson, 1985). However, this result questions the viability of plant populations in the inner field if viable source populations were not maintained in the neighbourhood. The fact that beta diversity decreased with increasing configurational crop heterogeneity in field interior transects suggests that landscape effects override the effects of spatial variability in within-field management practices classically resulting in high spatial variability in plant communities in field interiors (Gaméz-Virués et al., 2015). However, when separating field border and field interior transects, this effect was no longer significant.

In contrast, we observed no effect of configurational crop heterogeneity on plant diversity (alpha and gamma) in field borders. However, we detected a positive effect of compositional crop heterogeneity on alpha diversity, about half the effect of semi-natural cover when focusing only on field borders (Appendix S3). This suggests that landscape effects are more limited where plant richness is already high. Indeed, field borders are known to act as reservoir and corridor from and by which plant species may disperse (Marshall \& Moonen, 2002). Therefore, the maintenance of landscape connectivity through high field border length in agricultural landscapes is important to conserve diverse plant communities.

The discrepancy in the response of within-plant diversity to configurational crop heterogeneity between field borders and field interiors can be seen as a compensation for disturbances (through intensive management practices) by complex, high diversity crop mosaics (Tscharntke et al., 2005). Previous work suggested differences in impacts of farming practices within fields (Poggio et al., 2013) with lower intensity of farming practices such as herbicide applications near field borders (Marshall \& Moonen, 2002). We thus propose that, in field interiors where disturbance level is higher and colonization by short-distance dispersal events from surrounding patches more limited, increasing configurational crop heterogeneity would be more effective in enhancing species richness and diversity. Conversely, in field borders where disturbance level is lower and short-distance seed dispersal events are facilitated, increasing configurational crop heterogeneity would not result in locally enhanced plant diversity because plant diversity is already high. 
We could not properly test this hypothesis as spatial information about management practices was not available. However, assuming spatial heterogeneity in management impact between field borders and field interiors, our results are important for agri-environment schemes. They confirm that conservation of plant biodiversity in agricultural systems requires a landscape perspective (Tscharntke et al., 2005).

Besides the influence of configurational crop heterogeneity, we also detected a significant and positive effect of the amount of semi-natural cover types in the landscape on alpha and gamma diversity. This effect was slightly stronger than the effect of crop configurational heterogeneity (Table 2). This result provides additional evidence that increasing the amount of semi-natural cover in the landscape enhances local diversity in agroecosystems (Concepción, FernándezGonzález, \& Díaz, 2012; Tscharntke et al., 2005).

Finally, we showed that main relationships between crop heterogeneity and plant diversity hold true when accounting for crop type identity, or when focusing only on cereal fields, the most dominant crop type across our eight regions, or on grasslands (Appendix S4). However, the crop heterogeneity component differed with crop type, with a positive effect of crop compositional heterogeneity in cereals but a positive effect of configurational crop heterogeneity in grasslands. Further research is needed to identify the conditions (pedo-climatic context, crop type) and mechanisms involved, to understand under when increasing crop heterogeneity benefits plant diversity.

\section{5 | CONCLUSIONS}

Our study provides the first multi-country evidence that heterogeneity of the crop mosaic itself can provide additional benefits to semi-natural elements for the maintenance of plant diversity within agricultural fields. Our findings support the importance of adopting a landscape perspective in policy measures, perhaps adding to agrienvironmental schemes, to preserve within-field plant diversity and by extension, associated ecosystem services (Tscharntke et al., 2005).

The length of field borders benefits plant diversity as much as semi-natural cover. Thus, managing configurational crop heterogeneity opens new effective and complementary approaches to farmland biodiversity conservation (Batáry et al., 2017; Fahrig et al., 2015; Martin et al., 2019; Sirami et al., 2019; Solé-Senan, Juárez-Escario, Conesa, \& Recasens, 2018). By increasing plant diversity within-field, the increase of field border length may also contribute to increase the provisioning and spatial continuity of floral resource for organisms ensuring ecological functions beneficial to agricultural production, such as pollination and pest regulation (Vialatte et al., 2017). To do so will require the development of policy measures aiming at increasing configurational crop heterogeneity such as changing field shape to increase field border length, restoring margins or sowing in-field strips while maintaining habitats for viable source plant populations. Such policies could be favourably perceived by farmers and constitute a valuable alternative to agri-environmental schemes as they do not require taking land out of agricultural production and as machinery efficiency does not decrease significantly in smaller fields (Rodríguez \& Wiegand, 2009). Isolating economic effects of landscape fragmentation, Latruffe and Piet (2014) showed that decreasing field size reduces productivity as well as total technical efficiency (that is to say whether farmers operate their farm efficiently and whether the farm's production scale is optimal) but increases gross product and profitability.

We are aware that these recommendations may have trade-offs. We recognize that reversing the trend of the loss of plant diversity in agro-ecosystems is not usually within the farmers' top objectives and that there may be a conflict between weed management and biodiversity conservation. We argue that the choice of cropping systems (which includes crop rotation) and specific management strategies can help determine the pool of non-crop species present in each field (Smith \& Mortensen, 2017). Furthermore, the maintenance of higher crop diversity can help prevent the development of single, problematic weed species in the long term (Blackshaw, Anderson, \& Lemerle, 2007; Melander, Rasmussen, \& Barberi, 2005; Smith \& Mortensen, 2017). We also recognize that increasing the amount of field borders (to increase configurational crop heterogeneity) might have negative side effects on natural areas. Despite extensive research showing that vegetated field borders contribute to reduce pesticide transport by run-off, some authors reported that field borders might also constitute a source of pollutant run-off (e.g. Sheppard, Sheppard, Long, Sanipelli, \& Tait, 2006). Biodiversity in natural areas may then be at significant ecotoxicological risk from drift nearby such borders. In conclusion, managing heterogeneity of the crop mosaic itself appears as a promising alternative way to preserve farmland biodiversity even in landscapes dominated by intensively cultivated lands.

\section{ACKNOWLEDGEMENTS}

This work was funded by the ERA-Net BiodivERsA, with the national funders French National Research Agency (ANR-11-EBID-0004), German Ministry of Research and Education, German Research Foundation and Spanish Ministry of Economy and Competitiveness, part of the 2011 BiodivERsA call for research proposals. The contribution from the United Kingdom was funded by the UK Government Department of the Environment, Food and Rural Affairs (Defra), as project WC1034. The Canadian component of this research was funded by a Natural Sciences and Engineering Research Council of Canada (NSERC) Strategic Project grant, the Canada Foundation for Innovation, Environment Canada (EC) and Agriculture and Agri-Foods Canada (AAFC). We thank Yann Fillatre, Bastien Lamouroux, Annie Ouin and Jérôme Willm for field assistance. We thank all farmers and farm owners who graciously permitted us to work in their fields as well as all people and technical staff involved in geomatic analyses, plant surveys and species identification. We are grateful to all FarmLand partners for stimulating discussions. Finally, we would like to thank the associate editor, Pieter De Frenne, and two anonymous reviewers for their very constructive comments on an earlier version of the manuscript.

\section{AUTHORS' CONTRIBUTIONS}

L.F., J.-L.M., G.S., V.B., L.B., F.B., B.P., T.T. and P.B. conceived the idea and designed methodology within the FarmLand project; A.A., X.O.S.-S., I.R., B.B., D.G., N.G., J.R., C.S., G.S., A.B.B., C.B., R.C., A.H., L.H., P.M., I.B., G.B., F.C., Y.C., R.G., J.G., K.L., J.M., S.M., N.P., A.V. 
and N.Y. collected data. A.A., X.O.S.-S., I.R., B.P., L.F., D.G., N.G., J.L.M., J.R., C.S., G.S. and P.B. analysed the data. A.A. led the writing of the manuscript. All authors contributed critically to the drafts and gave final approval for publication.

\section{DATA AVAILABILITY STATEMENT}

Data are available via the Dryad Digital Repository https://doi.org/ 10.5061/dryad.t76hdr7xh (Alignier et al., 2020).

\section{ORCID}

Audrey Alignier (iD https://orcid.org/0000-0002-7619-7124 Xavier O. Solé-Senan (iD https://orcid.org/0000-0002-1533-1334 Lenore Fahrig (iD https://orcid.org/0000-0002-3841-0342 David Giralt iD https://orcid.org/0000-0001-9712-1957 Nicolas Gross iD https://orcid.org/0000-0001-9730-3240 Jordi Recasens (DD https://orcid.org/0000-0003-2304-0032 Clélia Sirami iD https://orcid.org/0000-0003-1741-3082 Colette Bertrand iD https://orcid.org/0000-0003-0599-3331 Annika Hass (iD https://orcid.org/0000-0002-3377-4622 Paul Miguet (iD https://orcid.org/0000-0003-2099-0729 Isabelle Badenhausser (iD https://orcid.org/0000-0002-6919-8647 Jacques Baudry (iD https://orcid.org/0000-0001-9324-970X Vincent Bretagnolle iD https://orcid.org/0000-0002-2320-7755 Kathryn Lindsay iD https://orcid.org/0000-0001-8763-1937 Scott Mitchell iD https://orcid.org/0000-0003-4657-0706 Cyrille Violle iD https://orcid.org/0000-0002-2471-9226

\section{REFERENCES}

Alignier, A., Petit, S., \& Bohan, D. A. (2017). Relative effects of local management and landscape heterogeneity on weed richness, density, biomass and seed rain at the country-wide level, Great Britain. Agriculture, Ecosystems and Environment, 246, 12-20. https://doi. org/10.1016/j.agee.2017.05.025

Alignier, A., Solé-Senan, X.O., Robleño, I., Baraibar, B., Fahrig, L., ... Batáry, P. (2020). Data from: Configurational crop heterogeneity increases within-field plant diversity. Dryad Digital Repository, https:// doi.org/10.5061/dryad.t76hdr7xh

Auerbach, M., \& Shmida, A. (1987). Spatial scale and the determinants of plant species richness. Trends in Ecology and Evolution, 2, 238-242. https://doi.org/10.1016/0169-5347(87)90005-X

Barton, K. (2017). MuMIn: Multi-model inference. R package version 1.40.0. https://CRAN.R-project.org/package=MuMIn

Batáry, P., Gallé, R., Riesch, F., Fischer, C., Dormann, C. F., Mußhoff, O., ... Tscharntke, T. (2017). The former Iron Curtain still drives biodiversityprofit trade-offs in German agriculture. Nature Ecology and Evolution, 1, 1279-1284. https://doi.org/10.1038/s41559-017-0272-x

Bates, D., Maechler, M., Bolker, B., \& Walker, S. (2015). Fitting linear mixed-effects models using Ime4. Journal of Statistical Software, 67, 1-48.

Benton, T. G., Vickery, J. A., \& Wilson, J. D. (2003). Farmland biodiversity: Is habitat heterogeneity the key? Trends in Ecology and Evolution, 18, 182-188. https://doi.org/10.1016/S0169-5347(03)00011-9

Bertrand, C., Burel, F., \& Baudry, J. (2016). Spatial and temporal heterogeneity of the crop mosaic influences carabid beetles in agricultural landscapes. Landscape Ecology, 31, 451-466. https://doi. org/10.1007/s10980-015-0259-4

Blackshaw, R. E., Anderson, R. L., \& Lemerle, D. (2007). In M. K. Upadhyaya \& R. E. Blackshaw (Eds.), Non-chemical weed management.
Principles, concepts and technology (pp. 35-47). Wallingford, UK: CAB International. Retrieved from www.cabi.org

Bosem Baillod, A., Tscharntke, T., Clough, Y., \& Batáry, P. (2017). Landscapescale interactions of spatial and temporal cropland heterogeneity drive biological control of cereal aphids. Journal of Applied Ecology, 54, 1804-1813. https://doi.org/10.1111/1365-2664.12910

Bretagnolle, V., \& Gaba, S. (2015). Weeds for bees? A review. Agronomy for Sustainable Development, 35, 891-909. https://doi.org/10.1007/ s13593-015-0302-5

Burnham, K. P., \& Anderson, D. R. (2002). Model selection and multimodel inference: A practical information-theoric approach (2nd ed.). New York, NY: Springer Verlag.

Burton, R. J. F., Kuczera, C., \& Schwarz, G. (2008). Exploring farmers' cultural resistance to voluntary agri-environmental schemes. Sociologia Ruralis, 48, 16-37. https://doi.org/10.1111/j.1467-9523.2008.00452.x

Concepción, E. D., Fernández-González, F., \& Díaz, M. (2012). Plant diversity partitioning in Mediterranean croplands: Effects of farming intensity, field edge, and landscape context. Ecological Applications, 22, 972-981. https://doi.org/10.1890/11-1471.1

Core Team, R. (2015). R: A language and environment for statistical computing. Vienna, Austria: R Foundation for Statistical Computing. Retrieved from https://www.R-project.org/

Fahrig, L., Baudry, J., Brotons, L., Burel, F. G., Crist, T. O., Fuller, R. J., ... Martin, J.-L. (2011). Functional landscape heterogeneity and animal biodiversity in agricultural landscapes. Ecology Letters, 14, 101-112. https://doi.org/10.1111/j.1461-0248.2010.01559.x

Fahrig, L., Girard, J., Duro, D., Pasher, J., Smith, A., Javorek, S., ... Tischendorf, L. (2015). Farmlands with smaller crop fields have higher within-field biodiversity. Agriculture, Ecosystems and Environment, 200, 219-234. https://doi.org/10.1016/j.agee.2014.11.018

Foley, J. A., Ramankutty, N., Brauman, K. A., Cassidy, E. S., Gerber, J. S., Johnston, M., ... Zaks, D. P. M. (2011). Solutions for a cultivated planet. Nature, 478, 337. https://doi.org/10.1038/nature10452

Fried, G., Petit, S., Dessaint, F., \& Reboud, X. (2009). Arable weed decline in Northern France: Crop edges as refugia for weed conservation? Biological Conservation, 142, 238-243. https://doi.org/10.1016/j. biocon.2008.09.029

Gámez-Virués, S., Perović, D. J., Gossner, M. M., Börschig, C., Blüthgen, N., de Jong, H., ... Westphal, C. (2015). Landscape simplification filters species traits and drives biotic homogenization. Nature Communications, 6, 8568. https://doi.org/10.1038/ncomms9568

Gargominy, O., Tercerie, S., Régnier, C., Ramage, T., Schoelinck, C., Dupont, P., ... Poncet, L. (2014). TAXREF v8. 0, référentiel taxonomique pour la France: Méthodologie, mise en œuvre et diffusion. Paris, France: Muséum National d'Histoire Naturelle. Rapport SPN 2014-42, 126 pp.

Grueber, C. E., Nakagawa, S., Laws, R. J., \& Jamieson, I. G. (2011). Multimodel inference in ecology and evolution: Challenges and solutions. Journal of Evolutionary Biology, 24, 699-711. https://doi. org/10.1111/j.1420-9101.2010.02210.x

Hass, A. L., Kormann, U. G., Tscharntke, T., Clough, Y., Baillod, A. B., Sirami, C., ... Batáry, P. (2018). Landscape configurational heterogeneity by small-scale agriculture, not crop diversity, maintains pollinators and plant reproduction in western Europe. Proceedings of the Royal Society B, 285, 20172242. https://doi.org/10.1098/rspb.2017.2242

Henckel, L., Börger, L., Meiss, H., Gaba, S., \& Bretagnolle, V. (2015). Organic fields sustain weed metacommunity dynamics in farmland landscapes. Proceedings of the Royal Society B: Biological Sciences, 282(1808), 20150002-https://doi.org/10.1098/rspb.2015.0002

José-María, L., Armengot, L., Blanco-Moreno, J. M., Bassa, M., \& Sans, F. $X$. (2010). Effects of agricultural intensification on plant diversity in Mediterranean dry-land cereal fields. Journal of Applied Ecology, 47, 832-840. https://doi.org/10.1111/j.1365-2664.2010.01822.x

Kareiva, P., Watts, S., McDonald, R., \& Boucher, T. (2007). Domesticated nature: Shaping landscapes and ecosystems for human welfare. Science, 316, 1866-1869. https://doi.org/10.1126/science.1140170 
Landis, D. A., \& Marino, P. C. (1999). Landscape structure and extra-field processes: Impact on management of pests and beneficiais. In Handbook of pest management (pp. 101-126). Boca Raton, FL: CRC Press.

Latruffe, L., \& Piet, L. (2014). Does land fragmentation affect farm performance? A case study from Brittany, France. Agricultural Systems, 129, 68-80. https://doi.org/10.1016/j.agsy.2014.05.005

Lososová, Z., Chytrý, M., Cimalova, S., Kropáč, Z., Otýpková, Z., Pyšek, P., \& Tichý, L. (2004). Weed vegetation of arable land in Central Europe: Gradients of diversity and species composition. Journal of Vegetation Science, 15, 415-422. https://doi.org/10.1111/j.1654-1103.2004. tb02279.x

Marshall,E.J.P.(2009).Theimpactoflandscapestructureandsowngrassmargin strips on weed assemblages in arable crops and their boundaries. Weed Research, 49, 107-115. https://doi.org/10.1111/j.1365-3180.2008. 00670.x

Marshall, E. J. P., Brown, V. K., Boatman, N. D., Lutman, P. J. W., Squire, G. R., \& Ward, L. K. (2003). The role of weeds in supporting biological diversity within crop fields. Weed Research, 43, 77-89. https://doi. org/10.1046/j.1365-3180.2003.00326.x

Marshall, E. J. P., \& Moonen, A. C. (2002). Field margins in northern Europe: Their functions and interactions with agriculture. Agriculture, Ecosystems and Environment, 89, 5-21. https://doi.org/10.1016/ S0167-8809(01)00315-2

Martin, E. A., Dainese, M., Clough, Y., Báldi, A., Bommarco, R., Gagic, V., ... Steffan-Dewenter, I. (2019). The interplay of landscape composition and configuration: New pathways to manage functional biodiversity and agroecosystem services across Europe. Ecology Letters, 22, 1083-1094. https://doi.org/10.1111/ele.13265

Melander, B., Rasmussen, I. A., \& Barberi, P. (2005). Integrating physical and cultural methods of weed control-examples from European research. Weed Science, 53(3), 369-381. https://doi.org/10.1614/ WS-04-136R

Nakagawa, S., \& Schielzeth, H. (2013). A general and simple method for obtaining $R^{2}$ from generalized linear mixed-effects models. Methods in Ecology and Evolution, 4, 133-142.

Newbold, T., Hudson, L. N., Hill, S. L., Contu, S., Lysenko, I., Senior, R. A., ... Purvis, A. (2015). Global effects of land use on local terrestrial biodiversity. Nature, 520(7545), 45-50.

Norris, K. (2008). Agriculture and biodiversity conservation: Opportunity knocks. Conservation Letters, 1, 2-11. https://doi.org/10.1111/ j.1755-263X.2008.00007.x

Palmu, E., Ekroos, J., Hanson, H. I., Smith, H. G., \& Hedlund, K. (2014). Landscape-scale crop diversity interacts with local management to determine ground beetle diversity. Basic and Applied Ecology, 15, 241-249. https://doi.org/10.1016/j.baae.2014.03.001

Pasher, J., Mitchell, S. W., King, D. J., Fahrig, L., Smith, A. C., \& Lindsay, K. E. (2013). Optimizing landscape selection for estimating relative effects of landscape variables on ecological responses. Landscape Ecology, 28, 371-383. https://doi.org/10.1007/s10980-013-9852-6

Perović, D., Gámez-Virués, S., Börschig, C., Klein, A.-M., Krauss, J., Steckel, J., ... Westphal, C. (2015). Configurational landscape heterogeneity shapes functional community composition of grassland butterflies. Journal of Applied Ecology, 52, 505-513. https://doi. org/10.1111/1365-2664.12394

Petit, S., Alignier, A., Colbach, N., Joannon, A., Le Cœur, D., \& Thenail, C. (2013). Weed dispersal by farming at various spatial scales. A Review. Agronomy for Sustainable Development, 33, 205-217. https:// doi.org/10.1007/s13593-012-0095-8

Poggio, S. L., Chaneton, E. J., \& Ghersa, C. M. (2013). The arable plant diversity of intensively managed farmland: Effects of field position and crop type at local and landscape scales. Agriculture, Ecosystems and Environment, 166, 55-64. https://doi.org/10.1016/j.agee.2012.01.013

Rodríguez, C., \& Wiegand, K. (2009). Evaluating the trade-off between machinery efficiency and loss of biodiversity-friendly habitats in arable landscapes: The role of field size. Agriculture, Ecosystems and Environment, 129, 361-366. https://doi.org/10.1016/j.agee.2008.10.010

Roschewitz, I., Gabriel, D., Tscharntke, T., \& Thies, C. (2005). The effects of landscape complexity on arable weed species diversity in organic and conventional farming. Journal of Applied Ecology, 42, 873-882. https://doi.org/10.1111/j.1365-2664.2005.01072.x

Sheppard, S. C., Sheppard, M. I., Long, J., Sanipelli, B., \& Tait, J. (2006). Runoff phosphorus retention in vegetated field margins on flat landscapes. Canadian Journal of Soil Science, 86, 871-884. https://doi.org/ 10.4141/S05-072

Shmida, A., \& Wilson, M. V. (1985). Biological determinants of species diversity. Journal of Biogeography, 12,1-20. https://doi.org/10.2307/2845026

Sirami, C., Gross, N., Baillod, A. B., Bertrand, C., Carrié, R., Hass, A., ... Fahrig, L. (2019). Increasing crop heterogeneity enhances multitrophic diversity across agricultural regions. Proceedings of the National Academy of Sciences of the United States of America, 116(33), 16442-16447. https://doi.org/10.1073/pnas.1906419116

Smith, R. G., \& Mortensen, D. A. (2017). A disturbance-based framework for understanding weed community assembly in agroecosystems: Challenges and opportunities for agroecological weed management. In A. Wezed (Ed.), Agroecological practices for sustainable agriculture: Principles, applications, and making the transition (pp. 127-153). Lyon, France: World Scientific.

Solé-Senan, X. O., Juárez-Escario, A., Conesa, J. A., \& Recasens, J. (2018). Plant species, functional assemblages and partitioning of diversity in a Mediterranean agricultural mosaic landscape. Agriculture, Ecosystems and Environment, 256, 163-172. https://doi.org/10.1016/ j.agee.2018.01.014

Solé-Senan, X. O., Juárez-Escario, A., Conesa, J. A., Torra, J., Royo-Esnal, A., \& Recasens, J. (2014). Plant diversity in Mediterranean cereal fields: Unraveling the effect of landscape complexity on rare arable plants. Agriculture, Ecosystems and Environment, 185, 221-230. https://doi.org/10.1016/j.agee.2014.01.003

Storkey, J. (2006). A functional group approach to the management of UK arable weeds to support biological diversity. Weed Research, 46, 513-522. https://doi.org/10.1111/j.1365-3180.2006.00528.x

Tscharntke, T., Klein, A. M., Kruess, A., Steffan-Dewenter, I., \& Thies, C. (2005). Landscape perspectives on agricultural intensification and biodiversity-ecosystem service management. Ecology Letters, 8, 857-874.

Tscharntke, T., Tylianakis, J. M., Rand, T. A., Didham, R. K., Fahrig, L., Batáry, P., ... Westphal, C. (2012). Landscape moderation of biodiversity patterns and processes-eight hypotheses. Biological Reviews, 87, 661-685. https://doi.org/10.1111/j.1469-185X.2011.00216.x

Vialatte, A., Tsafack, N., Hassan, D. A., Duflot, R., Plantegenest, M., Ouin, A., ... Ernoult, A. (2017). Landscape potential for pollen provisioning for beneficial insects favours biological control in crop fields. Landscape Ecology, 32, 465-480. https://doi.org/10.1007/ s10980-016-0481-8

Whittaker, R. H. (1972). Evolution and measurement of species diversity. Taxon, 21, 213-251. https://doi.org/10.2307/1218190

\section{SUPPORTING INFORMATION}

Additional supporting information may be found online in the Supporting Information section.

How to cite this article: Alignier A, Solé-Senan XO, Robleño I, et al. Configurational crop heterogeneity increases withinfield plant diversity. J Appl Ecol. 2020;00:1-10. https://doi. org/10.1111/1365-2664.13585 